УДК 338.1:001.895(100)

https://doi.org/10.24866/1813-3274/2021-1/27-37

М. С. Сысоева ${ }^{1}$, Институт экономики, управления и сервиса Тамбовского государственного университета имени Г. Р. Державина, г. Тамбов, Россия E-mail: ms_sysoeva@mail.ru

\title{
ОТЕЧЕСТВЕННЫЙ И ЗАРУБЕЖНЫЙ ОПЫТ ВНЕДРЕНИЯ ЭФФЕКТИВНЫХ ИННОВАЦИЙ
}

Аннотация. В статье представлен отечественный и зарубежный опыт выстраивания эффективной инновационной деятельности. Кризис 2020 г. изменил привычный уклад мироустройства. Кризис, начавшийся в здравоохранении в Китае, привёл к глобальному пересмотру существования всех сфер жизнедеятельности во всех странах мира. Разворачивающийся в настоящее время экономический кризис резко сократил расходы на исследования и инновации в компаниях, в то время как обременённые долгами правительства столкнулись с многочисленными конкурирующими потребностями в финансовой поддержке. Однако, как показывает история, после каждого кризиса начинается новый виток развития, который, как правило, связан с прорывными технологиями и внедрением эффективных инноваций. Рассмотрены основные источники финансирования НИОКР. Внедрение и использование эффективных инноваций в разных странах происходит по-разному и зависит от заинтересованности самого государства в данных инновациях, что выражается в инвестициях в инновационную деятельность. Выделены отличия построения инновационной деятельности в Российской Федерации и развитых странах. В Российской Федерации наблюдается отличие по соотношению источников финансирования. Развитые страны тратят миллиарды долларов на поддержку прорывных технологий, которые в последующем внедряются в их хозяйственную практику. Это позволяет экономикам этих государств оставаться конкурентоспособными. За счёт повышения производительности труда удаётся нивелировать недостатки, такие как отсутствие собственных природных ресурсов, небольшие территориальные размеры и рост числа стареющего населения. Несмотря на то, что в структуре валовых внутренних расходов на НИОКР по источникам финансирования в развитых стра-

\footnotetext{
${ }^{1}$ Маргарита Сергеевна Сысоева, доцент кафедры бухгалтерского учёта и налогового контроля Института экономики, управления и сервиса, Тамбовский государственный университет имени Г. Р. Державина, г. Тамбов, Россия.

Для ичитирования: Сысоева М. С. Отечественный и зарубежный опыт внедрения эффективных инноваций // Азиатско-Тихоокеанский регион: экономика, политика, право. 2021. №. 1. С. 27-37. https://doi.org/10.24866/1813-3274/2021-1/27-37.

(C) Сысоева М. С., 2021
} 
нах основную часть занимают коммерческие предприятия, роль государства заключается не только в финансировании. Государству для улучшения своих позиций в мировом инновационном пространстве необходимо привести в соответствие статистические показатели к показателям международных организаций; эффективнее использовать государственно-частное партнёрство с целью привлечения частного капитала в финансирование инноваций и снижения оттока научных кадров; расширять налоговые и кредитные льготы для деятельности предприятий в сфере инноваций; формировать эффективную инфраструктуру для осуществления инноваций; развивать человеческий капитал посредством культурного просвещения нации.

Ключевые слова: эффективные инновации, источники финансирования, наукоёмкая продукция, государственно-частное партнёрство, научно-исследовательские и опытно-конструкторские работы (НИОКР), развитые страны, образование, глобальный инновационный индекс, человеческий капитал, инновационная среда.

Margarita S. Sysoeva ${ }^{1}$, Institute of Economics, Management and Service of Tambov State University named after G. R. Derzhavin, Tambov, Russia E-mail: ms_sysoeva@mail.ru

\section{DOMESTIC AND FOREIGN EXPERIENCE OF IMPLEMENTING EFFECTIVE INNOVATIONS}

Abstract. The article presents domestic and foreign experience in building effective innovative activities. The 2020 crisis has changed the usual way of world order. The crisis that began in China's healthcare has led to a global rethinking of the existence of all spheres of life in all countries of the world. The unfolding economic crisis has sharply reduced research and innovation spending in companies, while debt-ridden governments are faced with numerous competing needs for financial support. However, as history shows, after each crisis, a new round of development begins, which, as a rule, is associated with breakthrough technologies and the introduction of effective innovations. The main sources of R\&D funding are considered. The introduction and use of effective innovations in different countries occurs in different ways and depends on the interest of the state itself in these innovations, which is expressed in investments in innovative activities. The differences in the construction of innovative activities in the Russian Federation and developed countries are

\footnotetext{
${ }^{1}$ Margarita Sergeevna Sysoeva, Associate Professor of the Department of Accounting and Tax Control of the Institute of Economics, Management and Service, Tambov State University named after G. R. Derzhavin, Tambov, Russia.

For citing: Sysoeva M. S. Domestic and foreign experience of implementing effective innovations // PACIFIC RIM: Economics, Politics, Law. 2021. No. 1. P. 27-37. https://doi.org/10.24866/1813-3274/20211/27-37.
} 
highlighted. In the Russian Federation, there is a difference in the ratio of funding sources. Developed countries spend billions of dollars to support breakthrough technologies, which are subsequently introduced into their economic practice. This allows the economies of these states to remain competitive. By increasing labor productivity, it is possible to neutralize disadvantages such as the lack of its own natural resources, small territorial size and an increase in the number of an aging population. Despite the fact that in the structure of gross domestic expenditures on R\&D by sources of financing in developed countries the main part is occupied by commercial enterprises, the role of the state is not only in financing. To improve its position in the global innovation space, the state needs to bring statistical indicators into line with those of international organizations; more efficiently use public-private partnerships in order to attract private capital to finance innovation and reduce the outflow of scientific personnel; expand tax and credit incentives for enterprises in the field of innovation; create an effective infrastructure for innovation; to develop human capital by means of cultural education of the nation.

Keywords: effective innovations, funding sources, high technology products, publicprivate partnerships, research and development work (R\&D), developed countries, education, global innovation index, human capital, innovation environment.

Кризис 2020 г. изменил привычный уклад мироустройства. Обычно кризис затрагивает лишь один какой-либо аспект - финансы, политику, здравоохранение, экологию - и не все страны одновременно. Кризис, начавшийся в здравоохранении в Китае, привёл к глобальному пересмотру существования всех сфер жизнедеятельности во всех странах мира [2]. В данных условиях началась рецессия во всех областях экономики. Разворачивающийся в настоящее время экономический кризис резко сократил расходы на исследования и инновации в компаниях, в то время как обременённые долгами правительства столкнулись с многочисленными конкурирующими потребностями в финансовой поддержке. Однако, как показывает история, после каждого кризиса начинается новый виток развития, который, как правило, связан с прорывными технологиями и внедрением эффективных инноваций. Поэтому изучение опыта ведущих стран в сфере организации инновационной деятельности является весьма актуальным вопросом.

Цель работы заключается в изучении и сравнении особенностей внедрения эффективных инноваций в развитых странах и в Российской Федерации и на этой основе - разработке рекомендаций по повышению конкурентоспособности Российской Федерации в данной сфере.

Осуществление поставленной цели предполагает решение следующих задач: определить содержание инновационной деятельности и эффективных инноваций; изучить источники финансирования инновационной деятельности; выявить лиде- 
ров наукоёмких отраслей; определить место России в мировой экономике инноваций; предложить рекомендации по повышению эффективности внедрения эффективных инноваций в Российской Федерации.

Изучение поставленных задач основано на приёмах и методах статистического, экономико-математического анализа, а также методах сравнения и группировок.

Эффективные инновации по своей сути являются сложным элементом человеческой жизнедеятельности. От идеи до внедрения продукта проходит достаточно продолжительное время, поэтому процесс внедрения требует детального рассмотрения.

Внедрение и использование эффективных инноваций в разных странах происходит по-разному и зависит от заинтересованности самого государства в данных инновациях, что выражается в инвестициях в инновационную деятельность. Целью производства инновационных продуктов является удовлетворение нужд и потребностей конечных пользователей, то есть населения, которые формируются, как правило, не одновременно с развитием рынка.

Ключевым индикатором инновационного развития страны являются затраты на научно-исследовательские и опытно-конструкторские разработки. Являясь относительной величиной, они рассчитывается путём сложения всех затрат на НИОКР, как государственных, так и частных в течение года. В табл. 1 представлены данные о валовых внутренних расходах (ВР) на НИОКР в развитых странах за 20052018 гг.

Таблица 1

Валовые внутренние расходы на НИОКР (ВРНИОКР)

в текущих ценах и ППС за 2005-2018 гг., млрд долл. [3; 4; 5]

\begin{tabular}{|l|l|l|l|l|l|l|l|}
\hline \multicolumn{1}{|c|}{$\begin{array}{c}\text { Государства, } \\
\text { союзы }\end{array}$} & 2005 & 2013 & 2014 & 2015 & 2016 & 2017 & 2018 \\
\hline $\begin{array}{l}\text { Европейский } \\
\text { Союз (28 стран) }\end{array}$ & 226 & 355 & 371 & 386 & 406 & 438 & 464 \\
\hline $\begin{array}{l}\text { Российская } \\
\text { Федерация }\end{array}$ & 18 & 38 & 40 & 38 & 39 & 42 & 41 \\
\hline Китай & 86 & 323 & 346 & 366 & 393 & 420 & 468 \\
\hline США & 328 & 454 & 476 & 495 & 516 & 548 & 581 \\
\hline Япония & 128 & 164 & 169 & 168 & 160 & 166 & 171 \\
\hline $\begin{array}{l}\text { Развитые страны } \\
\text { в целом* }\end{array}$ & 779 & 1149 & 1202 & 1240 & 1286 & 1369 & 1447 \\
\hline
\end{tabular}

*Австралия, Австрия, Бельгия, Великобритания, Венгрия, Германия, Греция, Дания, Израиль, Ирландия, Исландия, Испания, Италия, Канада, Колумбия, Латвия, Литва, Люксембург, Мексика, Нидерланды, Новая Зеландия, Норвегия, Польша, Португалия, Словакия, Словения, США, Турция, Финляндия, Франция, Чехия, Чили, Швейцария, Швеция, Эстония, Республика Корея, Япония. 
Валовые внутренние затраты на научно-исследовательские и опытно-конструкторские разработки за 2005-2018 г. увеличились в Европейском Союзе, Китае, США, Япония. В Российской Федерации до 2018 г. наблюдался рост данного показателя, однако в 2018 г. произошло сокращение на 1 млрд долл. Наиболее высокий темп роста валовых внутренних расходов на НИОКР в Китае, они увеличились в 5,5 раз. За аналогичный период расходы в США увеличились с 328 млрд долл. до 581 млрд долл., т.е. на 177\%, в Японии на 133\%, в Европейском Союзе на 205\%. Из представленных данных очевидно, что РФ значительно отстаёт от наиболее развитых стран по данному показателю в абсолютном значении.

Расходы на НИОКР в РФ составляют лишь 8\% от расходов Европейского Союза, $8 \%$ от расходов Китая, $7 \%$ от расходов США и $24 \%$ от расходов Японии. Абсолютным лидером по валовым внутренним расходам на НИОКР являются США. В 2018 г. на эти цели они направили 581 млрд долл., что составляет 40\% от расходов всех развитых стран в целом (1447 млрд долл.).

На рис. 1 представлены графики валовых внутренних расходов на НИОКР (ВРНИОКР) в процентах от ВВП.

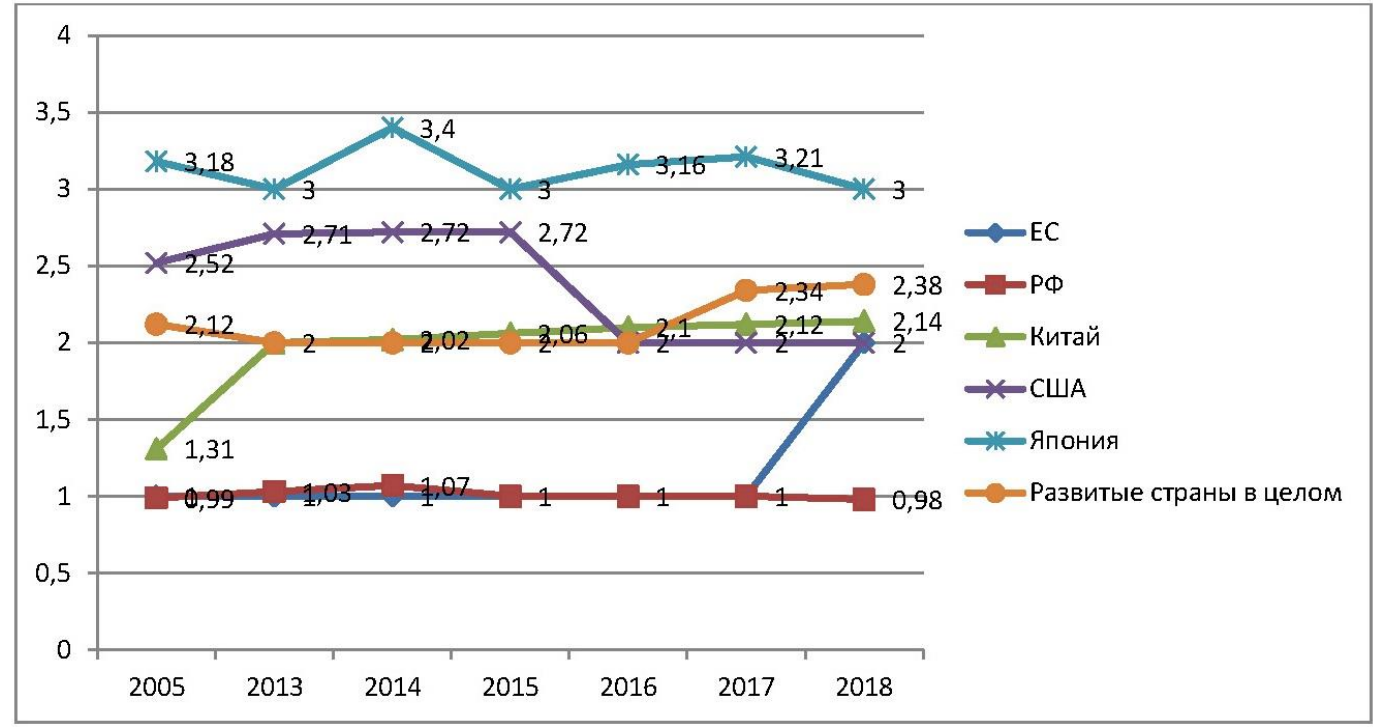

Рис. 1. Изменение валовых внутренних расходов на НИОКР в процентах от ВВП по странам за 2005-2018 гг. [3; 4; 5]

Ежегодные валовые внутренние расходы всех развитых стран выросли на 85\%, с 779 млрд долл. до 1447 млрд долл. При этом их вложения в НИОКР были выше, чем темп их экономического роста; рост расходов на НИОКР по отношению к ВВП был всего лишь на $0,26 \%$ (2,38\% - 2,12\%). Наибольшая доля валовых внутренних 
расходов на НИОКР в 2018 г. в Японии - 3,28\%, наименьшая в РФ - 0,98\%, у остальных стран доля от 2\% до $3 \%$.

Развитые страны тратят миллиарды долларов на поддержку прорывных технологий, которые в последующем внедряются в их хозяйственную практику. Это позволяет экономикам этих государств оставаться конкурентоспособными. За счёт повышения производительности труда удаётся нивелировать недостатки, такие как отсутствие собственных природных ресурсов, небольшие территориальные размеры и рост числа стареющего населения (рис. 2). В целом это позволяет улучшать уровень жизни своих граждан за счёт улучшения условий труда, возможности получения высокотехнологичной медицинской помощи, современного передового образования. Под влиянием новых знаний и технологий постоянно происходит трансформация экономической деятельности.

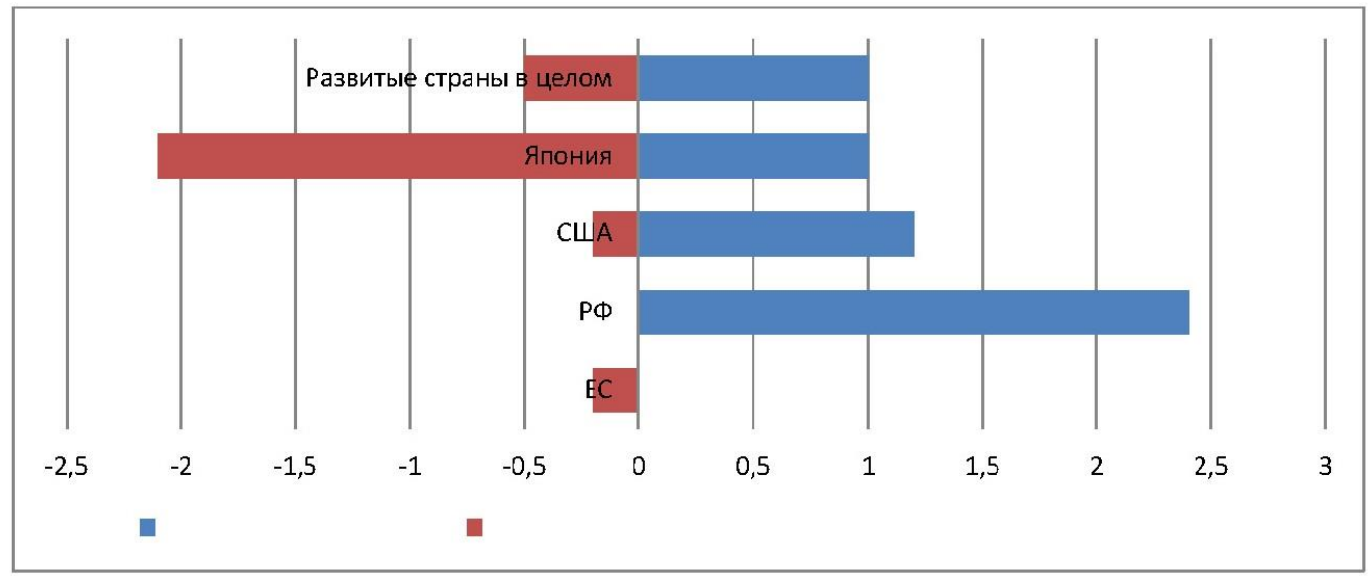

Puc. 2. Зависимость прироста ВВП на душу населения от изменения производительности и продолжительности труда по странам в 2019 г. [3; 4; 5]

Каждая страна отличается численностью населения, поэтому необходимо рассмотреть и такой показатель, как валовые внутренние расходы на НИОКР (ВРНИОКР) на душу населения в текущих ценах и ППС (рис. 3).

Динамика валовых внутренних расходов на НИОКР на душу населения в текущих ценах и ППС по странам за 2005-2018 г. подтверждает, что США являются мировым лидером в области прорывных технологий и эффективных инноваций. Данный показатель на протяжении анализируемого периода рос и в 2018 г. составил 1776 долл. на душу населения. Далее следует Япония - 1354 долл. на душу населения, Европейский Союз - 905 долл. на душу населения, Китай - 335 долл. на душу населения, РФ - 282 долл. на душу населения.

Развитые страны уделяют большое внимание инновационным технологиям, что подтверждается данными статистики. На протяжении 13 лет они лишь увели- 
чивали расходы на НИОКР как в абсолютном отношении, так и наращивали долю расходов от ВВП, валовые внутренние расходы на НИОКР на душу населения также росли. Однако РФ уступает значительно по данным показателям. Доля расходов от ВВП за анализируемый период всегда примерно в рамках 1\%, а в 2018 г. снизилась до минимума и составила 0,98\%. Несмотря на то, что численность населения РФ уменьшалась до 2012 г., а с 2012 г. до 2018 г. незначительно увеличилась, валовые внутренние расходы на НИОКР на душу населения составляли 260-280 долл. за 2005-2018 гг., что говорит о стагнации инновационной деятельности и ухудшении финансовой стабильности, в частности из-за санкционной агрессивной политики других стран по отношению к РФ.

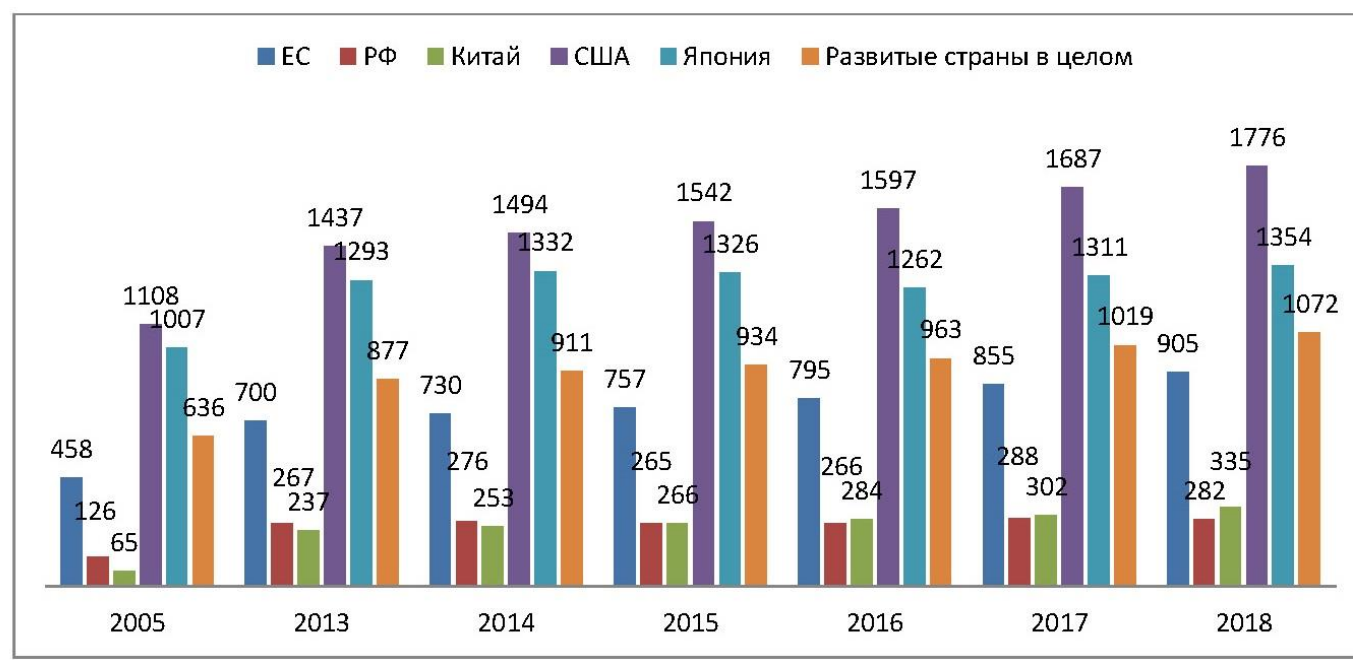

Puc. 3. Изменение валовых внутренних расходов на НИОКР на душу населения в текущих ценах и ППС по странам за 2005-2018 гг., долл. [3; 4; 5]

Постоянный рост инвестиций в НИОКР развитыми странами позволяют им оставаться мировыми лидерами наукоёмкой продукции и знаниеёмкого производства (рис. 4).

Как видим, Российская Федерация, обладающая значительными территориальными, природными и человеческими ресурсами, занимает минимальную долю в экспорте наукоёмкой продукции. Также для мирового сообщества характерна специализация, как правило, только на одной какой-либо сфере. Лидеры мирового рынка экспортируют не только готовые изделия, но и сами технологии. Для РФ характерно обратное, экспорт природных ресурсов занимает весомую долю ВВП.

В Европейском Союзе половина предприятий (50,3\%), на которых работает не менее 10 человек, сообщили об инновационной активности за трехлетний период, 2016-2018 гг., что немного больше, чем в период 2014-2016 гг. (49,5\%). В Эстонии $(73,1 \%)$, Кипре $(68,2 \%)$, Бельгии и Германии (по 67,8\%), Италии $(63,2 \%)$, Швеции 
$(63,1 \%)$, Австрии (62,6\%), Финляндии $(61,9 \%)$ и Греции $(60,3 \%)$ всего было более $60 \%$ инновационных предприятий. Напротив, эта доля составляла около $30 \%$ или меньше в Румынии (14,6\%), Польше (23,7\%), Венгрии (28,7\%) и Болгарии (30,1\%) [5].
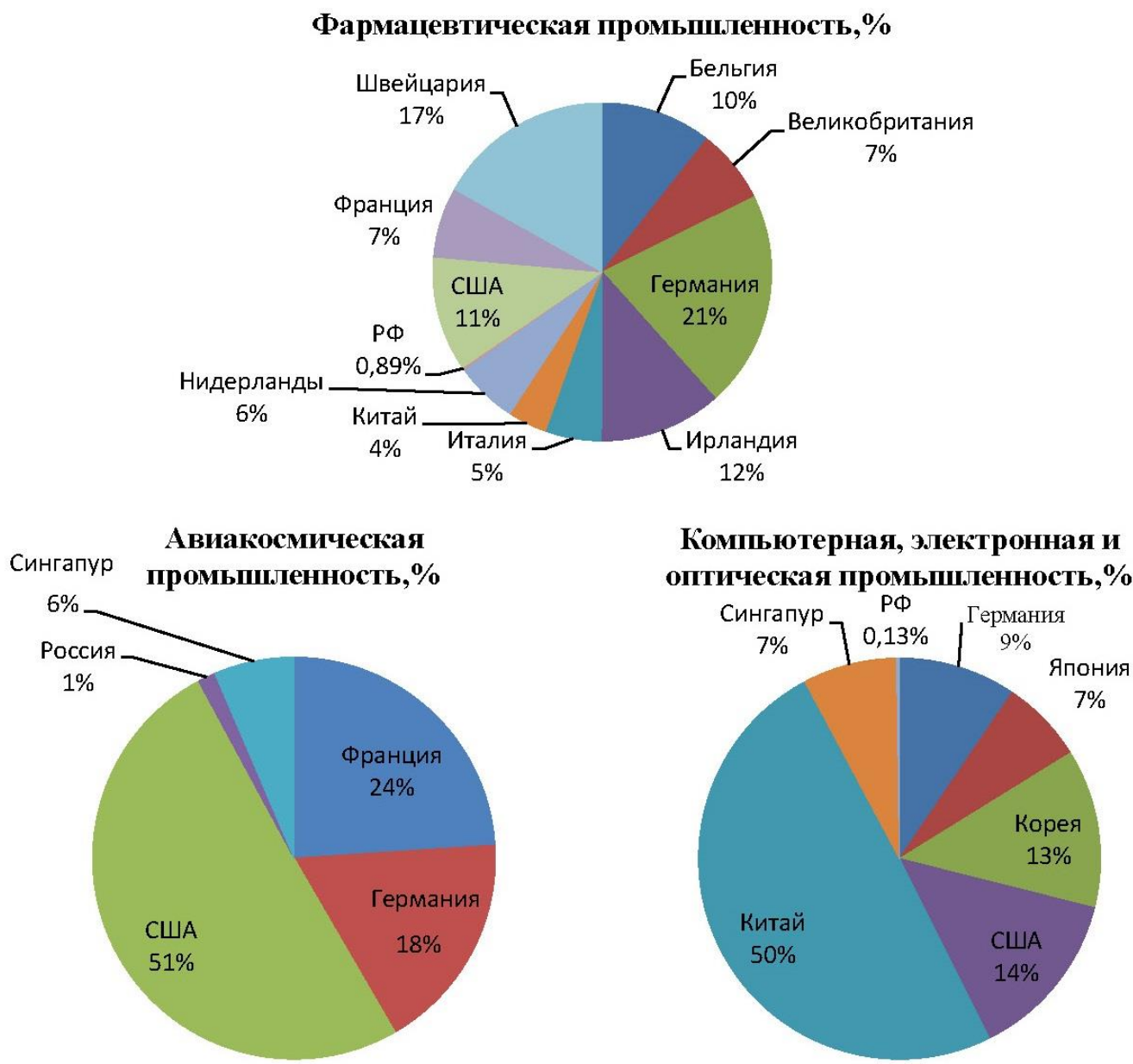

Puc. 4. Доля экспортного рынка наукоёмкой продукции в 2018 г. [3; 4; 5]

Основой развития прогрессивных технологий, продукции и услуг в развитых странах является заинтересованность не только государства, но и частных компаний [1]. Причём с каждым годом объём финансирования инновационной деятельности частными компаниями только увеличивается (рис. 5).

По рис. 5 можно проследить тенденцию взаимодействия государства и коммерческих предприятий при финансировании НИОКР в соотношении как 1:2 или 1:3 в пользу коммерческих предприятий, при этом даются значительные льготы и преференции коммерческим предприятиям на инновационную деятельность. 
Сысоева М. С. Отечественный и зарубежный опыт внедрения эффективных инноваций

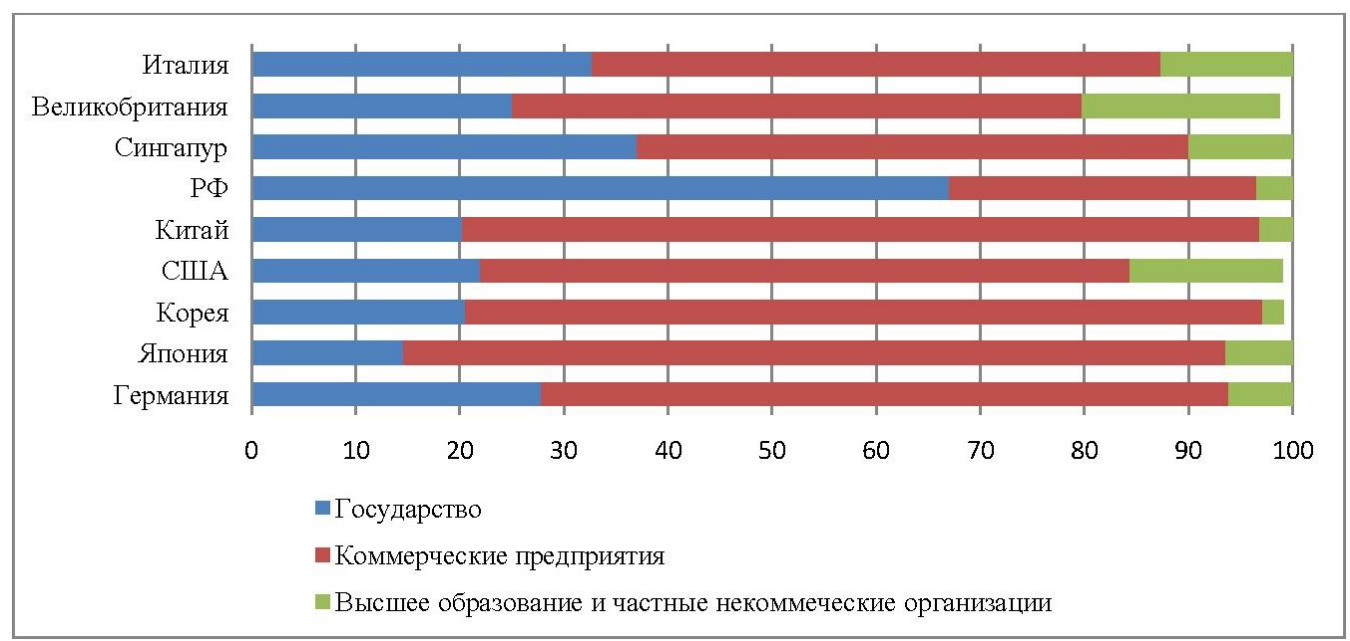

Puc. 5. Структура валовых внутренних расходов на НИОКР по источникам финансирования в 2018 г., \% [3; 4; 5]

Однако в Российской Федерации наблюдается отличие по соотношению источников финансирования. Наибольшую долю занимают государственные источники финансирования. По сравнению с наиболее развитыми странами, инновационная деятельность в Российской Федерации носит тенденцию инертности, что подтверждается глобальным инновационным индексом (ГИИ).

Глобальный инновационный индекс сформирован из 80 показателей, объединённых в направления (институты, инфраструктура, результаты креативной деятельности, уровень развития рынка, развитие технологий и экономики знаний, уровень развития бизнеса, человеческий капитал и наука) по 131 стране. По результатам проведенного исследования, в 2020 г. Российская Федерация занимает 47-е место, что ниже на одну позицию по сравнению с предыдущим периодом. Возглавляют данный рейтинг развитые страны, такие как Швейцария, Швеция и США. Динамика позиций РФ в Глобальном инновационном индексе представлена в табл. 2.

Таблица 2

Динамика позиций РФ в ГИИ в 2015-2020 гг. [6]*

\begin{tabular}{|l|c|c|c|c|c|c|}
\hline Годы & 2015 & 2016 & 2017 & 2018 & 2019 & 2020 \\
\hline $\begin{array}{l}\text { ГИИ } \\
\text { место РФ } \\
\text { в рейтинге) }\end{array}$ & $\mathbf{4 8}$ & $\mathbf{4 3}$ & $\mathbf{4 5}$ & $\mathbf{4 6}$ & $\mathbf{4 6}$ & $\mathbf{4 7}$ \\
\hline $\begin{array}{l}\text { Ресурсы } \\
\text { инноваций }\end{array}$ & 52 & 44 & 43 & 43 & 41 & 42 \\
\hline $\begin{array}{l}\text { Результаты } \\
\text { инноваций }\end{array}$ & 49 & 47 & 51 & 56 & 59 & 58 \\
\hline
\end{tabular}

*Количество стран: 2015 г. - 141; 2016 г. - 128; 2017 г. - 127; 2018 г. - 126; 2019 г. $129 ; 2020$ г. -131. 
Несмотря на то, что в структуре валовых внутренних расходов на НИОКР по источникам финансирования в развитых странах основную часть занимают коммерческие предприятия, роль государства заключается не только в финансировании. На рис. 6 представлено сравнение позиций России по элементам глобального инновационного индекса.

Недостаточная эффективность инноваций определяется слабой развитостью инновационной инфраструктуры, а также институтов, создающих условия для коммерческих предприятий. Развитие Российской Федерации находится на уровне третьего и четвёртого технологического уклада, развитие пятого происходит, в отличие от других развитых стран, медленнее.

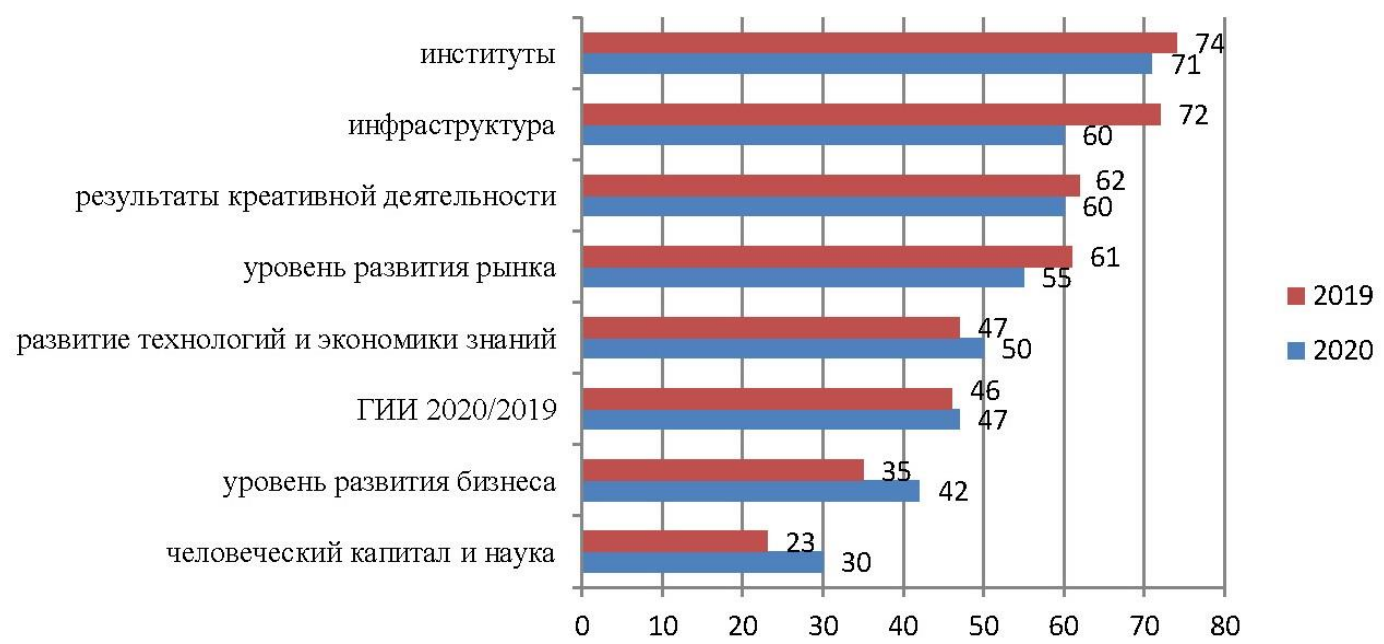

Puc. 6. Позиции России в ГИИ-2019 и ГИИ-2020 по элементам инновационного индекса [6]

Российской Федерации с целью повышения конкурентоспособности в области внедрения передовых технологий и продуктов необходимо:

- привести свои статистические показатели в соответствие с показателями международных организаций;

- эффективнее использовать государственно-частное партнёрство с целью привлечения частного капитала в финансирование инноваций и снижения оттока научных кадров;

- расширять налоговые и кредитные льготы для инновационной деятельности предприятий;

- формировать эффективную инфраструктуру инноваций;

- развивать человеческий капитал посредством культурного просвещения нации.

Реализация мер по эффективному внедрению инноваций должна привести к улучшению инновационного климата для бизнес-структур и повысить конкурентоспособность страны в целом в системе международных отношений. 


\section{Список литературы}

1. Соловьева, Ю. Н. Структура источников финансирования НИОКР в разных странах / Ю. Н. Соловьева, И. А. Галанина // Научные записки ТОГУ. - 2017. - Т. 8 , № 4. - C. 296-301.

2. Сысоева, М. С. Влияние экономического кризиса 1998, 2008 и 2020 годов на бизнес-структуры: сравнительный аспект / М. С. Сысоева, И. Н. Махонина // Проблемы развития народного хозяйства на современном этапе : материалы междунар. науч.-практ. конф., 25 ноября 2020 г. / под ред. А. А. Бурмистрова [и др.] ; Московский гос. ун-т науки и высшего образования Рос. Федерации, ФГБОУ ВО «Тамбовский гос. ун-т им. Г. Р. Державина». - Тамбов : Державинский, 2020. - С. 325-333.

3. Организация экономического сотрудничества и развития : офиц. сайт. URL: http://www.oecd.org/ (дата обращения: 15.03.2021).

4. Федеральная служба государственной статистики Российской Федерации : офиц. сайт. - URL: www.gks.ru (дата обращения: 15.03.2021).

5. EUROSTAT. - URL: https://ec.europa.eu/eurostat (дата обращения: 15.03.2021).

6. Глобальные инновации Index-2020. - URL: https://issek.hse.ru/news/39612 0793.html (дата обращения: 15.03.2021).

\section{References}

1. Solov'eva Yu. N., Galanina I. A. Struktura istochnikov finansirovaniya NIOKR v raznykh stranakh [Structure of sources of R\&D financing in different countries]. Nauchnye zapiski TOGU, 2017, vol. 8, no 4, pp. 296-301.

2. Sysoeva M. S., Mahonina I. N. Vliyanie ekonomicheskogo krizisa 1998, 2008 i 2020 godov na biznes-struktury: sravnitel'nyi aspekt [The impact of the economic crisis of 1998, 2008, and 2020 on business structures: a comparative aspect]. In: Problemy razvitiya narodnogo khozyaistva na sovremennom etape: materialy Mezhdunarodnoi nauchno-prakticheskoi konferentsii. 25 noyabrya 2020 g. / pod red. A. A. Burmistrova [i $d r$.] [Burmistrov A. A. et al., eds. Problems of the development of the national economy at the present stage: materials of the International Scientific and Practical Conference. November 25, 2020]. Tambov: Publ. House «Derzhavinsky», 2020, pp. 325-333.

3. Official website Organisation for Economic Cooperation and Development. Available at: http://www.oecd.org/ (accessed 15 March 2021).

4. Official website of the Federal State Statistics Service of the Russian Federation. Available at: www.gks.ru. (accessed 15 March 2021).(In Russian).

5. EUROSTAT. Available at: https://ec.europa.eu/eurostat. (accessed 15 March 2021).

6. Global Innovation Index-2020. Available at: https://issek.hse.ru/news/39612079 3.html (accessed 15 March 2021). (in Russian) 